\title{
Pure red cell aplasia caused by D-penicillamine treatment of rheumatoid arthritis
}

\author{
M Tishler, Y Kahn, M Yaron
}

\begin{abstract}
A 40 year old woman with rheumatoid arthritis developed pure red cell aplasia after treatment with D-penicillamine $500 \mathrm{mg} /$ day. D-Penicillamine was stopped and short term treatment with steroids resulted in complete recovery of bone marrow.
\end{abstract}

Although D-penicillamine has been found to be effective in the treatment of rheumatoid arthritis, the incidence of complications has been reported to be as high as $60 \%$. $^{1}$ Blood dyscrasias and bone marrow aplasia have been reported previously, some of them with fatal outcome. $^{2}$ Pure red cell aplasia has been associated with rheumatoid arthritis, and many drugs, including non-steroidal anti-inflammatory drugs, have been incriminated in the development of such aplasia. ${ }^{3}$ To our knowledge, however, D-penicillamine has not been reported as the cause of pure red cell aplasia in patients with rheumatoid arthritis. We report the case of a patient who developed pure red cell aplasia while taking penicillamine. Cessation of treatment and institution of steroids resulted in complete recovery.

\section{Case report}

A 40 year old woman had a two year history of seropositive erosive rheumatoid arthritis. After treatment with a variety of non-steroidal antiinflammatory drugs treatment with $D$-penicillamine $250 \mathrm{mg} /$ day was started in August 1988 with gradual improvement in her clinical condition. Laboratory tests showed a haemoglobin of $128 \mathrm{~g} / 1$ with normal white cell and platelet counts and a sedimentation rate of $25 \mathrm{~mm} / \mathrm{h}$. In June 1989 because of a flare of her disease the dosage was raised to $500 \mathrm{mg} /$ day. Active synovitis subsided and since then the patient has taken only occasional paracetamol in addition. Routine blood tests performed a month later showed a haemoglobin of $73 \mathrm{~g} / 1$, packed cell volume 0.2 with $2 \cdot 1 \times 10^{6}$ red cells and $0.2 \%$ reticulocytes. Her white cell count was $6.3 \times 10^{9} / 1$ with a normal differential count, the platelet count was $474 \times 10^{9} / 1$, and the erythrocyte sedimentation rate was $89 \mathrm{~mm} / \mathrm{h}$. Bone marrow aspiration showed normal cellularity with increase in megakaryocytes, hyperplasia of myeloid series, and almost complete absence of erythroid precursors. Coombs' test was negative, serum iron and ferritin concen-
Laboratory results after stopping treatment with penicillamine

\begin{tabular}{lll}
\hline Date & $\begin{array}{l}\text { Haemoglobin } \\
(\boldsymbol{g} / \mathrm{l})\end{array}$ & $\begin{array}{l}\text { Reticulocytes } \\
(\%)\end{array}$ \\
\hline 2 Jun 1989 & 128 & ND $^{*}$ \\
5 July 1989 & 73 & $0 \cdot 2$ \\
16 July 1989 & 75 & $0 \cdot 5$ \\
30 July 1989 & 85 & $6 \cdot 0$ \\
13 Aug 1989 & 96 & $8 \cdot 0$ \\
3 Sept 1989 & 112 & $3 \cdot 0$ \\
8 Oct 1989 & 125 & $3 \cdot 0$ \\
\hline
\end{tabular}

${ }^{*} \mathrm{ND}=$ not done.

trations were high, while vitamin B-12 and folic acid were normal. Rheumatoid factor was positive at a titre of $1 / 5000$, and the concentration of all serum immunoglobulins was slightly raised. A chest radiograph was normal except for mild interstitial changes. A presumptive diagnosis of penicillamine induced pure red cell aplasia was made, the drug was stopped, and treatment with prednisone $30 \mathrm{mg} /$ day started. Her haemoglobin concentrations and reticulocyte counts increased gradually (table) and the prednisone dose was tapered. Three months later the patient had completely recovered and treatment was started with low dose methotrexate.

\section{Discussion}

Pure red cell aplasia is characterised by diminished or absent erythroblasts in the bone marrow with normal myeloid and megakaryocytic lineages. Laboratory examinations showed anaemia and reticulocytopenia with normal white cell and platelet counts. This selective damage of the erythroid lineage has been reported to occur with lymphoproliferative disorders, thymoma, neoplasms, autoimmune disorders, or to be drug related. ${ }^{4}$ An association between patients with untreated rheumatoid arthritis and pure red cell aplasia has been reported. ${ }^{5}$ Nevertheless, in most reports drugs have been incriminated in the cause of pure red cell aplasia: gold salts, ${ }^{6}$ azathioprine,${ }^{7}$ and nonsteroidal anti-inflammatory drugs. ${ }^{3}$ D-Penicillamine has been reported to cause transient bone marrow depression in up to $12 \%$ of patients, ${ }^{8}$ usually in a dose related mechanism. On the other hand, aplastic anaemia, which is serious and potentially life threatening, occurs as an idiosyncratic reaction only in some cases. ${ }^{8} 9$ Pure red cell aplasia attributed to D-penicillamine treatment has been reported in a patient 
taking the drug for more than 14 years for Wilson's disease. ${ }^{10}$ To our knowledge, however, this has not previously been reported as a cause for pure red cell aplasia in patients with rheumatoid arthritis. The concurrent use of paracetamol does not interfere with our conclusions as after withholding penicillamine treatment the bone marrow recovered despite the continuous use of the paracetamol. Pure red cell aplasia has commonly been shown to be an immunologically mediated syndrome ${ }^{11}$; it should therefore be treated with the same rationale as immune haemolytic anaemia. Most authors recommended giving prednisone up to $60 \mathrm{mg} /$ day for a period of four weeks and if no response occurs, cyclophosphamide can be added. $^{45}$ Our patient responded quickly to drug discontinuation and short term corticosteroid treatment. Doctors should be aware of this rare side effect and we re-emphasise the importance of frequent blood counts in patients receiving penicillamine treatment.
1 Magnus J H, Gran J T, Mikkelsen K, Mygaard H, Brath $\mathrm{H} \mathrm{K}$. Toxicity to D-penicillamine in rheumatoid arthritis. Scand I R heumatol 1987; 16: 441-4.

2 Fishel B, Tishler M, Caspi D, Yaron M. Fatal aplastic anaemia and liver toxicity caused by D-penicillamine treatment of rheumatoid arthritis. Ann Rheum Dis 1989; 48: treatmen

3 Michalevicz R, Baron S, Blum I. Fenbufen induced pure red cell aplasia in rheumatoid arthritis. $\mathcal{I}$ Reumatol 1987; 14: cell aplasia

4 Krantz S B. Pure red cell aplasia. In: Bruin M C, McCulloch P B, eds. Current therapy in hematology-oncology. St Louis: Mosby, 1983: 6-9.

5 Dessypris E N, Baer M R, Sergent J S, Krantz S B. Rheumatoid arthritis and pure red cell aplasia. Ann Intern Med 1984; 100: 202-6.

6 Reid G, Patterson A C. Pure red cell aplasia after gold treatment. $B M 7$ 1977; ii: 1457 .

7 McGrath B P, Ibels L S, Raik E, Hargrave M J. Erythroid toxicity of azathioprine macrocytosis and selective marrow hypoplasia. Am Y Med 1975; 44: 57-63.

8 Stein H B, Patterson A C, Offer R C, Atkins G J, Teufel A, Robinson H S. Adverse effects of D-penicillamine in rheumatoid arthritis. Ann Intern Med 1980; 92: 24-9.

9 Kay A G L. Myelotoxicity of D-penicillamine. Ann Rheum Dis 1979; 38: 232-6.

10 Gollan J L, Hussain S, Hoffbrand A V, Sherlock S. Red cell aplasia following prolonged D-penicillamine therapy. $f$ Clin Pathol 1976; 29: 135-9.

11 Krantz S B, Moore W H, Zaentz S D. Studies on red cell aplasia. V. Presence of erythroblast cytotoxicity in IgG globulin fraction of plasma. I Clin Invest 1973; 52: 324-36. 